\title{
Pengaruh Kompensasi Terhadap Kinerja Karyawan pada PT. Matahari Department Store Lippo Plaza Jambi
}

\author{
Muhammad Emil*, Diky Achmad Riandi \\ Fakultas Ekonomi Universitas Batanghari Jambi \\ *Correspondence email: muhammademil74@gmail.com, dickyachmadriandi@gmail.com
}

\begin{abstract}
This study aims to measure the influence of compensation on employee performance at PT. Matahari Department Store Lippo Plaza Jambi. This study also aims to determine whether the effect of compensation on performance and how much influence compensation on employee performance at PT. Matahari Department Store Lippo Plaza Jambi. This study uses quantitative methods with simple linear regression analysis methods, $t$ test, coefficient of determination, and is assisted by the SPSS 23 program. The types of data used in this study are primary and secondary data, and data is obtained through distributing questionnaires using the help of Google Forms as a questionnaire tool and literature study related to research. The results of simple linear regression analysis $Y=0.803+0.700 x+e$ in the partial test, it was found that the Compensation value was 0.000 less than the significance level of 0.5, meaning that compensation had an effect on performance. The magnitude of the effect of compensation on performance is evidenced by the regression coefficient and the result is 0.482 . From the regression coefficient analysis, the magnitude of the influence was $48.2 \%$, while the remaining $51.8 \%$ was influenced by other variables outside of this study. And it can be concluded based on statistical tests through tcount > ttable with tcount 7.779 while ttable 1.99714, so Ho is rejected Ha accepted, there is a significant influence between the compensation variable on performance.
\end{abstract}

Keywords: performance, compensation.

\section{Pendahuluan}

Di era globalisasi saat ini, dimana perkembangan zaman seiring dengan perkembangan teknologi yang semakin pesat tentunya tidak dapat dipungkiri bahwa perusahaan-perusahaan kelas menengah atas sangat berkaitan erat dengan penggunaan-penggunaan teknologi janggih yang dapat memperlancar kegiatan suatu perusahaan, namun terkadang sumber daya didalamnya kerap tidak mampu mengimbangi perkembangan yang ada sehingga membuat kinerja yang kurang maksimal, padahal kita perlu ketahui bahwa sumber daya manusia didalamnya menjadi salah satu faktor penting pendukung yang dimiliki perusahaan untuk memperlancar tujuan besar perusahaan demi kemajuan bersama. Maka dari itu perlu adanya faktor-faktor pendukung untuk meningkatkan kinerja karyawan, salah satunya peneliti tertarik untuk menganalisis peran Kompensasi terhadap faktor pendukung sebagai peningkatan kinerja karyawan, dimana dapat kita ketahui bahwa Kompensasi menurut Hasibuan (2012) menyatakan bahwa kompensasi adalah semua pendapatan yang berbntuk uang, barang langsung atau tidak langsung yang diterima karyawan sebagai imbalan atas jasa yang diberikan kepada perusahaan. Dari kutipan hasibuan bahwa ada benefit diluar gaji yang dapat di terima oleh karyawan dengan syarat dan ketentuan yang berlaku di dalam sebuah perusahaan.

Sedangkan kinerja menurut Menurut Sedarmayanti (2011) kinerja didefinisikan sebagai hasil kerja seorang pekerja, sebuah proses manajemen atau suatu organisasi secara keseluruhan, dimana hasil kerja tersebut dapat ditunjukan buktinya secara konkrit dan dapat diukur (dibandingkan dengan standar yang telah ditentukan. Peneliti memilih PT. Matahari Department Store Lippo Plaza Jambi, dimana perusahaan ini bergerak di bidang retail fashion yang memiliki penyebaran gerai store terbesar di seluruh Indonesia untuk melihat seberapa pengaruh kompensasi terhadap kinerja karyawanya. Tujuan dari penelitian ini adalah untuk mengetahui pengaruh kompensasi terhadap kinerja Karyawan PT. Matahari Department Store Lippo Plaza Jambi.

\section{Tinjauan Pustaka \\ Manajemen Sumber Daya Manusia}

Manajemen sumber daya manusia menurut Hasibuan (2006) adalah ilmu dan seni mengatur hubungan dan peranan tenaga kerja agar efektif dan efisien membantu terwujudnya tujuan perusahaan, karyawan dan masyarakat. Manajemen sumber daya manusia menurut Mangkunegara (2002:2) adalah suatu perencanampengorganisasian, pelaksanaan, dan pengawasan terhadap pengadaan, pengembangan, pemberian balas jasa. Pengintegrasian, pemeliharaan dan pemisahan tenaga kerja dalam rangka mencapai tujuan organisasi. Dapat disimpulkan dari definisi di atas bahwa Manajemen sumber daya manusia adalah suatu ilmu atau cara bagaimana mengatur hubungan dan peranan sumber daya yang dimiliki oleh individu secara efisien dan efektif serta dapat digunakan secara maksimal sehingga tercapai tujuan bersama perusahaan, karyawan dan masyarakat menjadi maksimal. 


\section{Kompensasi}

Kompensasi mempunyai arti yang sangat luas, selain terdiri dari gaji dan upah, dapat pula berbentuk fasilitas perumahan, fasilitas kendaraan, pakaian seragam, tunjangan keluarga, tunjangan kesehatan, tunjangan pangan, dan masih banyak lagi yang diterima oleh karyawan secara tetap. Kompensasi menurut Hasibuan (2012) menyatakan bahwa kompensasi adalah semua pendapatan yang berbntuk uang, barang langsung atau tidak langsung yang diterima karyawan sebagai imbalan atas jasa yang diberikan kepada perusahaan.Kompensasi menurut Suyonto (2008) adalah konsep yang lebih luas, kompensasi adalah semua bentuk kembalian atau imbalan finansial, jasa-jasa berwujud dan tujuan-tujuan yang diperoleh sebagai dari sebuah hubungan kepegawaian. Kompensasi menurut Sedarmayanti (2011) adalah segala sesuatu yang diterima oleh pegawai sebagai balas jasa untuk kerja mereka. Berdasarkan pengertian diatas dapat disimpulkan bahwa kompensasi merupakan segala sesuatu yang diterima oleh karyawan yang diberikan kepada perusahaan sebagai balas jasa atas sumbangan tenaga dan pikiran kemajuan perusahaan.

\section{Kinerja}

Menurut Mangkunegara (2006) kinerja adalah hasil kerja yang secara kualitas dan kuantitas yang telah dicapai oleh seorang karyawan atau pegawai dalam mengembang tugasnya sesuai dengan tanggung jawab yang telah diberikan kepadanya. Yang dimaksud dengan kualitas disini adalah dilihat dari segi kebersihan, kehalusan dan ketelitian dalam menjalankan tugas dan pekerjaannya. Sedangkan yang dimaksud dengan kuantitas itu dilihat dari banyaknya jumlah pekerjaan yang harus diselesaikan oleh pegawai atau karyawan tersebut. Menurut Sedarmayanti (2011) kinerja didefinisikan sebagai hasil kerja seorang pekerja, sebuah proses manajemen atau suatu organisasi secara keseluruhan, dimana hasil kerja tersebut dapat ditunjukan buktinya secara konkrit dan dapat diukur (dibandingkan dengan standar yang telah ditentukan). Menurut Hasibuan (2007) kinerja diartikan sebagai hasil kerja yang telah dicapai oleh seseorang dalam menjalankan tugas-tugasnya berdasarkan kecerdasannya, usaha serta kesempatan yang dilakukannya.kinerja tinggi memerlukan membangun budaya yang kuat dan kompak mendukung setiap usaha yang diperlukan untuk menghasilkan hasil yang luar biasa. Dapat disimpulkan dari definisi diatas bahwa Kinerja adalah hasil kerja atau tingkat keberhasilan seseorang secara keseluruhan selama periode tertentu dalam melaksanakan tugas dibandingkan dengan berbagai kemungkinan, seperti standar hasil kerja, target atau sasaran atau kriteria yang telah ditentukan terlebih dahulu dan telah disepakati bersama.

\section{Dimensi dan Indikator Kompensasi}

Menurut Veithzal Rivai (2011), terdapat 2 (dua) dimensi dalam proses pemberian kompensasi, yaitu: (1) kompensasi finansial langsung, yaitu terdiri dari gaji, bonus, insentif; dan (2) kompensasi tidak langsung (fringe benefit), berupa fasilitas-fasilitas, seperti: asuransi-asuransi, tunjangan-tunjangan, uang pension dan lain-lain. Menurut Hasibuan (2009) indikator kompensasi dapat berupa: gaji, upah, upah insentif, benefit service.

\section{Dimensi dan Indikator Kinerja}

Menurut Motowidlo dan Van Scotter (Syarif, 2018) mengusulkan 2 (dua) dimensi kinerja, yaitu: (1) kinerja tugas, adalah prilaku yang terkait dengan mempertahankan serta melayani teknis inti dalam organisasi; dan (2) kinerja kontekstual, adalah adalah fungsi dari pengetahuan tentang kemampuan interpersonal seseorang yang mendukung lingkungan sosial yang lebih luas dimana teknis inti harus berfungsi. Sedangkan menurut (Sedarmayanti 2009) menyebutkan ukuran indikator kinerja yaitu sebagai berikut: kualitas kerja (quality of work), ketetapan waktu (pomtness), inisiatif (initiative), kemampuan (capability), komunikasi (commucication)

\section{Hubungan antara system Kompensasi dan kinerja Karyawan}

Salah satu cara menajemen untuk meningkatkan prestasi kerja, memotivasi dan meningkatkan kepuasan dan kinerja karyawan adalah melalui kompensasi (mathls clan Jackson, 2000). Secara sederhana kompensasi merupakan sesuatu yang diterima karyawan untuk balas jasa kerja mereka. Berbicara tentang kebijakan pemberian kompensasi, umunya hanya tertuju pada jumlah yang dibayarkan pada karyawan. Apabila jumlah kompensasi telah cukup memadai, berarti sudah cukup layak dan baik. Pemasalahan sebenarnya tidak sesederhana itu, sebab cukup memadai menurut kacamata perusahaan, belum tentu dirasakan cukup oleh karyawan yang bersangkutan.Untuk menciptakan efisien, sistem kompensasi harus juga sejalan dengan konteks organisasi (Tremblay dan Chenevert, 2011) hal ini dimaksudkan bahwa, sistem pembayaran dan pemberian kompensasi harus sesuai dengan peraturan dan penetapan dari pemsahaan dengan sistem penilaian kinerja karyawan untuk menciptakan keadilan dalam pemberian kompensasi pada seluruh karyawannya. Untuk kinerja optimal, sistem kompensasi harus terdiri dari kebijakan yang konsisten baik antara karyawan individu atau sendiri dan dengan kebijakan HRM lainnya. 


\section{Hipotesis}

Diduga kompensasi berpengaruh signifikan terhadap kinerja karyawan pada PT. Matahari Department Store Lippo Plaza Jambi.

a. Ha : Diduga kompensasi dapat berpengaruh signifikan terhadap kinerja karyawan pada PT. Matahari Department Store Lippo Plaza Jambi.

b. Ho : Diduga kompensasi tidak berpengaruh signifikan terhadap kinerja karyawan pada PT. Matahari Department Store Lippo Plaza Jambi.

\section{Metode}

Sumber data merupakan karyawan/karyawati PT. Matahari Department Store Lippo Plaza Jambi yang menjadi responden sebagai objek penelitian. Analisis regresi linier sederhana digunakan untuk melihat mana pengaruh kompensasi terhadap kinerja pada PT. Department Store Lippo Plaza Jambi digunakan rumus regresi linier sederhana yang diolah menggunakan alat bantu program SPSS. Menurut Supranto (2015) rumus regresi sederhana X terhadap Y adalah sebagai berikut : $\mathrm{Y}=\mathrm{a}+\mathrm{bX}+\mathrm{e}$

Dimana: $\mathrm{Y}=$ Kinerja PT.Matahari Departmen Store; $\mathrm{a}=$ Konstanta' $\mathrm{X}=$ Kompensasi; $\mathrm{b}=$ Koefisien regresi; $\mathrm{e}=$ Standar error

Uji determinasi (R2) merupakan suatu ukuran yang penting dalam regresi, karena dapat mengimpormasikan baik atau tidaknya model regresi yang terestimasi atau dengan kata lain angka tersebut dapat mengukur seberapa dekatkah garis regresi yang terestimasi dengan data yang sesungguhnya. Nilai koefisien determinasi (R2) ini mencerminkan seberapa besar variasi dari variable terikat $\mathrm{Y}$ dapat diterangkan oleh mama bebas $\mathrm{o}(\mathrm{R} 2=0)$, artinya variasi dari $\mathrm{Y}$ tidak dapat diterangkan sama sekali. sementara bila $\mathrm{R} 2=1$, artinya variasi $\mathrm{Y}$ secara keseluruhan dapat diterangkan oleh $\mathrm{X}$, dengan kata lain bila $\mathrm{R} 2-=1$, maka semua titik pengamatan berada tepat pada garis regresi. Dengan demikian baik atau buruknya suatu persamaan regresi ditentukan oleh Rznya yang mempunyai nilai 0 dan 1.

Uji t digunakan untuk menentukan apakah variable Kompensasi (X) berpengaruh secara signifikan menggunakan variable Kinerja personil (Y) rumus yang digunakan adalah :

1. Rancangan Hipotesis

- Ho : Tidak ada pengaruh dan signifikan, kompensasi terhadap kinerja karyawan.

- Ha : Ada pengaruh dan signifikan, Kompensasi terhadap kinerja karyawan.

2. Menghitung ttabel (Supardi, 2013:233) menentukan nilai ttabel yaitu didapat dari pembaca tabel distribusi $t$ untuk taraf signifikan (a tertentu) dan $\mathrm{dk}=\mathrm{n}-\mathrm{k}-\mathrm{l}$. Dalam hal ini = banyak pasang data ( banyaknya variable bebas, atau 67-1-1=65

3. Kriteria Keputusan Jika terhitung besar dari ttabel maka Ho ditolak dan H1 diterima artinya terdapat pengaruh Signifikan antara kompensasi terhadap kinerja karyawan. Jika thitung kecil dari ttabel maka H0 diterima dan $\mathrm{H} 1$ ditolak artinya tidak terdapat pengaruh signifikan antara kompensasi terhadap kinerja karyawan.

\section{Hasil}

Tabel 1

Hasil Uji Regresi Linier Sederhana

\begin{tabular}{|l|r|r|r|r|r|}
\hline \multicolumn{1}{|c|}{ Model } & \multicolumn{2}{|c|}{$\begin{array}{c}\text { Coefficients } \\
\text { Std. Error }\end{array}$} & $\begin{array}{c}\text { Standardized Coefficients } \\
\text { Beta }\end{array}$ & \multirow{2}{*}{ Sig. } \\
\hline 1 (Constant) & B &, 803 &, 326 &, 016 \\
Kompensasi & &, 770 &, 099 &, 694 & 7,779 \\
\hline
\end{tabular}

Sumber: Data olahan

Berdasarkan keterangan diatas diketahui bahwa persamaan regresinya adalah sebagai berikut :

$\mathrm{Y}=0,803+0,770 \mathrm{x}$

Nilai Konstanta $=0,803$, nilai konstanta positif menunjukan Pengaruh Positif Variabel Independent (Kompensasi), artinya apabila variabel Independent bersifat Konstans atau tidak dilaksanakan dengan baik maka nilai kinerja karyawan sebesar $=0,803$ skala/satuan. Kompensasi $(X)=0,770$, merupakan koefisien regresi variabel Kompensasi (X) Terhadap variabel Kinerja (Y), yang memiliki makna bahwa setiap penambahan satu nilai Kompensasi akan menaikan Nilai Kinerja karyawan sebesar 0,770, atau dengan kata lain apabila kompensasi dapat ditingkatkan kualitasnya sebesar 100 skala, maka hal itu akan diikuti pula dengan peningkatan kinerja karyawan sebesar 100 skala. Dengan kata lain terdapat pengaruf positif kompensasi terhadap kinerja karyawan pada PT. Matahari Department Store Lippo Plaza Jambi. 
Tabel 2

Hasil Korelasi dan Determinasi $\left(\mathbf{R}^{2}\right)$

\begin{tabular}{|l|l|l|r|r|}
\hline Model & R & R Square & Adjusted R Square & Std. Error of the Estimate \\
\hline 1 &, $694 a$ &, 482 &, 474 &, 44568 \\
\hline
\end{tabular}

Sumber: Data olahan

Berdasarkan Tabel 2 Koefisien korelasi antara Kompensasi (X) terhadap kinerja karyawan adalah 0,482, Cukup Erat antara antara Variabel Kompensasi (X) dan kinerja karyawan (Y). Dari hasil pengujian Hipotesis maka diperoleh nilai determinan $=r 2$. Sebesar 0,482 angka ini menyatakan bahwa variabel kompensasi $(X)$ mampu menjelaskan variabel kinerja (Y), Pada PT. Matahari Department Store Lippo Plaza Jambi sebesar 48,2\% sedangkan 51,8\% dipengaruhi variabel lain diluar yang diteliti. Berdasarkan Tabel 1 hasil perhitungan diperoleh angka t hitung sebesar $=7,779$. Sedangkan ttabel sebesar 1.99714. jadi thitung sebesar 7,779 > ttabel sebesar 1.99714. Keputusan dikarenakan t-hitung > t-tabel maka Ho ditolak dan Ha diterima, berarti ada pengaruh yang signifikan antara variabel kompensasi terhadap kinerja karyawan. Hasil penelitian ini menjawab hipotesis sesuai dengan yang diajukan yaitu kompensasi dengan skor 298 jika dari rentang skala maka kompensasi pada PT. Matahari Department Store Lippo Plaza Jambi dalam keadaan sangat tinggi, dan kinerja dengan skor 312 jika dari rentang skala maka kompensasi pada PT. Matahari Department Store Lippo Plaza Jambi dalam keadaan sangat tinggi. Dengan demikian maka kompensasi dan kinerja pada PT. Matahari Department Store Lippo Plaza Jambi dapat diterima.

\section{Simpulan}

Berdasarkan hasil penelitian dan pembahasan yang telah dilakukan maka dapat diambil kesimpulan sebagai berikut :

1. Kompensasi sebesar 299 (Sangat Tinggi) dan kinerja skornya sebesar 312 (Sangat Tinggi) pada PT. Matahari Department Store Lippo Plaza Jambi.

2. Kompensasi berpengaruh signifikan terhadap kinerja karyawan pada PT. Matahari Department Store Lippo Plaza Jambi berdasarkan uji statistic, diperoleh angka thitung sebesar $=7,779$. Sedangkan ttabel sebesar 1.99714. jadi thitung sebesar 7,779 > ttabel sebesar 1.99714. Keputusan dikarenakan thitung > ttabel maka Ho ditolak dan Ha diterima, berarti ada pengaruh yang signifikan antara variabel kompensasi terhadap kinerja karyawan.

\section{Daftar Pustaka}

Arikunto, (2006), Riset Sumber Daya Manusia, Jakarta.

Daft, Richard L, (2002), Manajemen Edisi Kelima Jilid Satu. Jakarta: Erlangga

Gomes, Faustino Cardoso. (2003). Manajemen Sumber Daya Manusia. Jakarta: Andi Offset

Handoko, (2000), Manajemen Sumber Daya Manusia

Hasibuan, (2016), Manajemen Sumber Daya Manusia, PT Bumi Aksara, Jakarta

Lies Indriyani. (2009). Analisis pengaruh kompensasi dan lingkungan kerja terhadap produktifitas kerja perawat dengan kepuasan kerja sebagai Variabel Mediasi. Jurnal Ekonomi-Manajemen-Akuntansi, No. 59, Th.XVI, $117-127$

Mangkunegara, (2006), Manajemen Sumber Daya Manusia Perusahaan, Remaja Rosdakarya, Bandung

Putri, (2012), Hubungan Kompensasi Terhadap Kinerja Karyawan Pada Biro Manajemen Sumber Daya Manusia PT. Jasa Marga (PERSERO) Tbk, Universitas Indonesia, Skripsi

Rivai,Veithzal. (2011), Manajemen Sumber Daya Manusia untuk Perusahaan: dari teori ke praktek, Jakarta: Raja Grafindo Persada

Stoner, A.F., (2006). Manajemen Sumber Daya Manusia. Jakarta: Bumi Aksara.

Samsudin, (2006), Manajemen Sumber Daya Manusia

Sedarmayanti, (2015), Manajemen Sumber Daya Manusia,

Septawan, (2014), Manajemen Sumber Daya Manusia,

Sinambela, (2016), Manajemen Sumber Daya manusia, PT Bumi aksara, Jakarta

Simamora, (2004), Manajemen Sumber Daya Manusia,

Supriyadi, H. (2015). Manajemen sumber daya manusia: menciptakan keunggulan bersaing berbasis kompetensi SDM. Yogyakarta: Andi.

Sutrisno, (2011), Kinerja Karyawan

Sugiyono, Danang, (2002), Teori kuesioner dan Analisa Data Sumber Daya Manusia (Praktek Penelitian), Cetakan 1, Yoghyakarta.

Suwanto, (2011), Manajemen Sumber Daya Manusia

Umar Husein, (2011), Riset Sumber Daya Manusia

Wibowo, (2011), Manajemen Kinerja. Jakarta: PT. Raja Grafindo Persada 